\title{
Analgesic Comparison of Perineural With Intravenous Dexamethasone on Interscalene Block for Shoulder Arthroscopy: a Meta-analysis of Randomized Controlled Trials
}

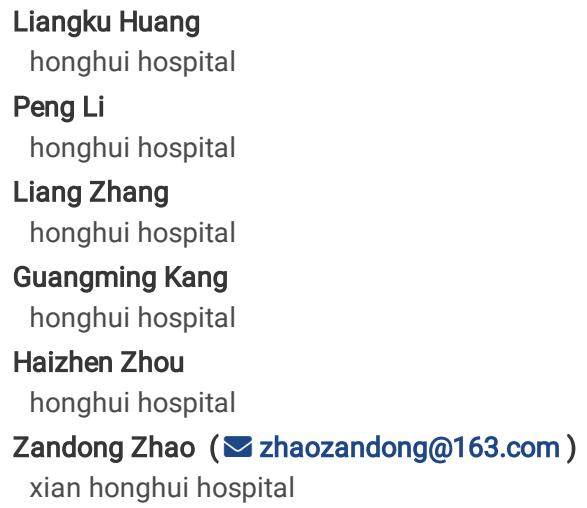




\section{Abstract}

Introduction: The analgesic comparison of perineural with intravenous dexamethasone on interscalene block for pain management of shoulder arthroscopy remains controversial. We conduct a systematic review and meta-analysis to explore the influence of perineural with intravenous dexamethasone on interscalene block on the postoperative pain intensity of shoulder arthroscopy.

Methods: We have searched PubMed, EMbase, Web of science, EBSCO, and Cochrane library databases through April 2021 for randomized controlled trials (RCTs) assessing the effect of perineural with intravenous dexamethasone on interscalene block for pain control of shoulder arthroscopy. This meta-analysis is performed using the random-effect model.

Results: Five RCTs are included in the meta-analysis. Overall, compared with intravenous dexamethasone for shoulder arthroscopy, perineural dexamethasone leads to similar block duration ( $S M D=0.12 ; 95 \% \mathrm{Cl}=-0.12$ to $0.35 ; \mathrm{P}=0.33)$, pain scores at $12 \mathrm{~h}(\mathrm{SMD}=-0.67 ; 95 \% \mathrm{Cl}=-1.48$ to $0.15 ; \mathrm{P}=0.11)$, pain scores at $24 \mathrm{~h}$ $(\mathrm{SMD}=-0.33 ; 95 \% \mathrm{Cl}=-0.79$ to $0.14 ; \mathrm{P}=0.17)$, opioid consumption $(\mathrm{SMD}=0.01 ; 95 \% \mathrm{Cl}=-0.18$ to $0.19 ; \mathrm{P}=0.95)$ and nausea/vomiting $(\mathrm{OR}=0.74 ; 95 \% \mathrm{Cl}=0.38$ to $1.44 ; \mathrm{P}=0.38)$

Conclusions: Perineural and intravenous dexamethasone demonstrated comparable pain control after shoulder arthroscopy when supplemented to interscalene block.

\section{Introduction}

Arthroscopy has been widely accepted to diagnose and treat shoulder diseases [1-3]. However, significant postoperative pain is a main concern after this surgery and effective analgesia is required for this successful day-case surgery [3-5]. Interscalene brachial plexus block (ISB) is the standard care for analgesia after shoulder surgery in terms of providing superior analgesia and reducing opioid consumption [6-8]. Single-injection ISB is limited by analgesic maintenance for several hours, and especially moderate to severe pain of this surgery requires opioid analgesia [9].

The increase in the dose of local anesthetic is used to prolong ISB, and has the limitation of narrow therapeutic window and volume/concentration. Volumes of $10 \mathrm{ml}$ or greater injected into the interscalene groove is associated with a high risk of ipsilateral hemi-diaphragmatic paresis [10]. Several adjuvants have been developed to prolong ISB. Especially, dexamethasone by perineural approach showed the potential in prolonging the duration of peripheral nerve blocks when in conjunction with local anesthetics [11].

Recently, several studies have explored the analgesic efficacy of perineural with intravenous dexamethasone for the pain management of shoulder arthroscopy, but the results are conflicting $[10,12,13]$. With accumulating evidence, we therefore perform this meta-analysis of RCTs to compare perineural with intravenous dexamethasone in patients with shoulder arthroscopy.

\section{Materials And Methods}

Ethical approval and patient consent are not required because this is a systematic review and meta-analysis of previously published studies. The systematic review and meta-analysis are conducted and reported in adherence to PRISMA (Preferred Reporting Items for Systematic Reviews and Meta-Analyses) [14, 15].

\section{Search strategy and study selection}

Two investigators have independently searched the following databases (inception to April 2021): PubMed, EMbase, Web of science, EBSCO, and Cochrane library databases. The electronic search strategy is conducted using the following keywords: dexamethasone, and interscalene block, and arthroscopy, and shoulder. We also check the reference lists of the screened full-text studies to identify other potentially eligible trials.

The inclusive selection criteria are as follows: (i) patients undergo shoulder arthroscopy; (ii) intervention treatments are perineural versus intravenous dexamethasone supplemented to interscalene block; (iii) study design is RCT.

\section{Data extraction and outcome measures}

We have extracted the following information: author, number of patients, age, female, body weight, American Society of Anesthesiologists (ASA) physical status and detail methods in each group etc. Data have been extracted independently by two investigators, and discrepancies are resolved by consensus. We also contact the corresponding author to obtain the data when necessary. The primary outcome is block duration. Secondary outcomes include pain scores at $12 \mathrm{~h}$, pain scores at $24 \mathrm{~h}$, opioid consumption, nausea/vomiting.

\section{Quality assessment in individual studies}

Methodological quality of the included studies is independently evaluated using the modified Jadad scale [16]. There are 3 items for Jadad scale: randomization (0-2 points), blinding (0-2 points), dropouts and withdrawals (0-1 points). The score of Jadad Scale varies from 0 to 5 points. An article with Jadad score $\leq 2$ is considered to be of low quality. If the Jadad score $\geq 3$, the study is thought to be of high quality [17].

\section{Statistical analysis}

We estimate the standard mean difference (SMD) with 95\% confidence interval (Cl) for continuous outcomes (block duration, pain scores at 12 h, pain scores at $24 \mathrm{~h}$ and opioid consumption) and odd ratios (ORs) with $95 \% \mathrm{Cls}$ for dichotomous outcomes (nausea/vomiting). The random-effects model is used regardless of heterogeneity. Heterogeneity is reported using the $\mathrm{I}^{2}$ statistic, and $\mathrm{I}^{2}>50 \%$ indicates significant heterogeneity [15, 18]. Whenever significant 
heterogeneity is present, we search for potential sources of heterogeneity via omitting one study in turn for the meta-analysis or performing subgroup analysis. All statistical analyses are performed using Review Manager Version 5.3 (The Cochrane Collaboration, Software Update, Oxford, UK).

\section{Results}

Literature search, study characteristics and quality assessment

A detailed flowchart of the search and selection results is shown in Fig. 1. 78 potentially relevant articles are identified initially. Finally, five RCTs that meet our inclusion criteria are included in the meta-analysis $[10,12,13,19,20]$.

The baseline characteristics of five eligible RCTs in the meta-analysis are summarized in Table 1 . The five studies are published between 2016 and 2020 , and total sample size is 585. The doses of perineural or intravenous dexamethasone supplemented to interscalene block range from $1 \mathrm{mg}$ to $5 \mathrm{mg}$. Among the five studies included here, three studies report block duration $[10,12,13]$, three studies report pain scores at $12 \mathrm{~h}[10,19,20]$, four studies report pain scores at $24 \mathrm{~h}$ $[10,12,19,20]$, three studies report opioid consumption $[10,12,13]$, and three studies report nausea/vomiting $[10,19,20]$. Jadad scores of the five included studies vary from 3 to 5 , and all five studies are considered to have high quality according to quality assessment.

Table 1

Characteristics of included studies

\begin{tabular}{|c|c|c|c|c|c|c|c|c|c|c|c|c|c|}
\hline \multirow[t]{2}{*}{ NO. } & \multirow[t]{2}{*}{ Author } & \multicolumn{6}{|c|}{ Perineural dexamethasone group } & \multicolumn{6}{|c|}{ Intravenous dexamethasone group } \\
\hline & & Number & $\begin{array}{l}\text { Age } \\
\text { (years) }\end{array}$ & $\begin{array}{l}\text { Female } \\
\text { (n) }\end{array}$ & $\begin{array}{l}\text { Weight } \\
\text { (kg) }\end{array}$ & $\begin{array}{l}\text { ASA } \\
\text { physical } \\
\text { status } \\
\text { (I/II/III) }\end{array}$ & Methods & Number & $\begin{array}{l}\text { Age } \\
\text { (years) }\end{array}$ & $\begin{array}{l}\text { Female } \\
\text { (n) }\end{array}$ & $\begin{array}{l}\text { Weight } \\
\text { (kg) }\end{array}$ & $\begin{array}{l}\text { ASA } \\
\text { physical } \\
\text { status } \\
\text { (I/II/III) }\end{array}$ & Metl \\
\hline 1 & $\begin{array}{l}\text { McHardy } \\
2020\end{array}$ & 92 & $\begin{array}{l}51.6 \\
(18- \\
73), \\
\text { median } \\
\text { (IQR) }\end{array}$ & 25 & - & $25 / 49 / 18$ & $\begin{array}{l}\text { interscalene } \\
\text { block analgesia } \\
\text { supplemented } \\
\text { with perineural } \\
\text { dexamethasone } \\
4 \mathrm{mg}\end{array}$ & 90 & $\begin{array}{l}52.8 \\
(22- \\
76), \\
\text { median } \\
\text { (IQR) }\end{array}$ & 21 & - & $18 / 57 / 15$ & $\begin{array}{l}\text { inter } \\
\text { bloc } \\
\text { supp } \\
\text { with } \\
\text { intra } \\
\text { dexé } \\
4 \text { me }\end{array}$ \\
\hline 2 & $\begin{array}{l}\text { Kahn } \\
2018\end{array}$ & 63 & $50 \pm 14$ & 26 & - & $22 / 38 / 3$ & $\begin{array}{l}\text { interscalene } \\
\text { block } \\
\text { supplemented } \\
\text { with perineural } \\
\text { dexamethasone } \\
2 \mathrm{mg}\end{array}$ & 62 & $47 \pm 15$ & 23 & - & $26 / 33 / 3$ & $\begin{array}{l}\text { inter } \\
\text { bloc } \\
\text { supr } \\
\text { with } \\
\text { intra } \\
\text { dexe } \\
1 \mathrm{me}\end{array}$ \\
\hline 3 & $\begin{array}{l}\text { Holland } \\
2018\end{array}$ & 70 & $54 \pm 12$ & 21 & $\begin{array}{l}87 \pm \\
16\end{array}$ & $24 / 40 / 6$ & $\begin{array}{l}\text { interscalene } \\
\text { block analgesia } \\
\text { supplemented } \\
\text { with perineural } \\
\text { dexamethasone } \\
4 \mathrm{mg}\end{array}$ & 69 & $53 \pm 14$ & 16 & $\begin{array}{l}89 \pm \\
17\end{array}$ & $21 / 44 / 5$ & $\begin{array}{l}\text { inter } \\
\text { bloc } \\
\text { supr } \\
\text { with } \\
\text { intra } \\
\text { dexé } \\
4 \mathrm{mr}\end{array}$ \\
\hline 4 & $\begin{array}{l}\text { Sakae } \\
2017\end{array}$ & 20 & $\begin{array}{l}53.2 \pm \\
9.8\end{array}$ & 8 & $\begin{array}{l}63.2 \pm \\
5.1\end{array}$ & $9 / 11 / 0$ & $\begin{array}{l}\text { interscalene } \\
\text { block analgesia } \\
\text { supplemented } \\
\text { with perineural } \\
\text { dexamethasone } \\
4 \mathrm{mg}\end{array}$ & 20 & $\begin{array}{l}52.1 \pm \\
12.3\end{array}$ & 6 & $\begin{array}{l}65.3 \pm \\
4.2\end{array}$ & $8 / 12 / 0$ & $\begin{array}{l}\text { inter } \\
\text { bloc } \\
\text { supr } \\
\text { with } \\
\text { intra } \\
\text { dexć } \\
4 \mathrm{mc}\end{array}$ \\
\hline 5 & $\begin{array}{l}\text { Chun } \\
2016\end{array}$ & 50 & $\begin{array}{l}50.8 \pm \\
17.5\end{array}$ & 17 & $\begin{array}{l}69.6 \pm \\
12.9\end{array}$ & $24 / 26 / 0$ & $\begin{array}{l}\text { interscalene } \\
\text { block analgesia } \\
\text { supplemented } \\
\text { with perineural } \\
\text { dexamethasone } \\
5 \mathrm{mg}\end{array}$ & 49 & $\begin{array}{l}53.0 \pm \\
14.2\end{array}$ & 15 & $\begin{array}{l}68.0 \pm \\
11.6\end{array}$ & $17 / 32 / 0$ & $\begin{array}{l}\text { inter } \\
\text { bloc } \\
\text { supp } \\
\text { with } \\
\text { intra } \\
\text { dexe } \\
5 \mathrm{me}\end{array}$ \\
\hline
\end{tabular}

\section{Primary outcome: block duration}

This outcome data is analyzed with the random-effects model, and compared to intravenous dexamethasone for shoulder arthroscopy, perineural dexamethasone results in similar block duration $(S M D=0.12 ; 95 \% \mathrm{Cl}=-0.12$ to $0.35 ; \mathrm{P}=0.33)$ with low heterogeneity among the studies $\left(\mathrm{I}^{2}=37 \%\right.$, heterogeneity $P=0.33)($ Fig. 2)

\section{Sensitivity analysis}

Low heterogeneity is observed among the included studies for the primary outcome, so we do not perform sensitivity analysis via omitting one study in turn to detect the heterogeneity. 
In comparison with intravenous dexamethasone for shoulder arthroscopy, perineural dexamethasone exhibits comparable pain scores at $12 \mathrm{~h}(\mathrm{SMD}=-0.67$; $95 \% \mathrm{Cl}=-1.48$ to $0.15 ; \mathrm{P}=0.11$; Fig. 3$)$, pain scores at $24 \mathrm{~h}(\mathrm{SMD}=-0.33 ; 95 \% \mathrm{Cl}=-0.79$ to $0.14 ; \mathrm{P}=0.17 ; \mathrm{Fig}$. 4), opioid consumption (SMD = $0.01 ; 95 \% \mathrm{Cl}=-0.18$ to $0.19 ; \mathrm{P}=0.95 ;$ Fig. 5) and nausea/vomiting ( $\mathrm{OR}=0.74 ; 95 \% \mathrm{Cl}=0.38$ to $1.44 ; \mathrm{P}=0.38 ;$ Fig. 6$)$.

\section{Discussion}

This serious pain after shoulder arthroscopy commonly occurs and mainly results from the insertion of arthroscopic instruments into the joint, soft tissue dissection and distention [21-25]. Patients' early mobilization and rehabilitation is significantly affected by this postoperative pain [26-28]. Numerous techniques have been studied, and ISB is widely accepted as the most effective analgesic technique for this surgery [3, 29-31]. Furthermore, supplementation with dexamethasone revealed significant role in increasing the duration and analgesic efficacy of ISB for shoulder arthroscopy [13, 19].

In order to study the better approach to use dexamethasone supplementation for ISB, our meta-analysis included five RCTs comparing perineural or intravenous dexamethasone supplementation for shoulder arthroscopy. The results revealed that perineural and intravenous dexamethasone resulted in comparable block duration, pain scores at $12 \mathrm{~h}$, pain scores at $24 \mathrm{~h}$ and opioid consumption when in conjunction with local analgesics for shoulder arthroscopy. Although the specific mechanism of dexamethasone remains unclear, it is postulated to reduce ectopic neuronal discharge and inhibit potassium channel-mediated discharge of nociceptive C-fibers [10, 32].

In consistent with our findings, previous study comparing perineural and systemic dexamethasone showed that both routes are associated with prolonged and similar block duration [33-35]. In contrast, one recent meta-analysis studied the dexamethasone supplementation for peripheral nerve block, and reported that perineural dexamethasone had a greater effect than systemic dexamethasone when used in conjunction with bupivacaine ( $4 \mathrm{~h})$ versus ropivacaine alone ( 2

h). This meta-analysis studied the postoperative pain of various types of surgeries, and showed extreme heterogeneity of results with $\mathrm{I}^{2}$ exceeding $90 \%$. Therefore, its results should be interpreted with caution [11].

In addition, the incidence of nausea/vomiting is similar between two groups based on our results. This meta-analysis also has several limitations. Firstly, our analysis is based on five RCTs, and two of them have a relatively small sample size $(n<100)$. Overestimation of the treatment effect is more likely in smaller trials compared with larger samples. Next, although there is low heterogeneity, different doses, concentration and combination methods of analgesics may produce some bias. Finally, it is not feasible to perform the meta-analysis of some important index such as discharge time and time to first analgesic requirement based on current RCTs.

\section{Conclusions}

Perineural and intravenous dexamethasone showed similar efficacy for block duration for shoulder arthroscopy when supplemented to local analgesics.

\section{Abbreviations}

randomized controlled trials: RCTs

mean differences: MDs

confidence intervals: Cls

risk ratios: RRs

\section{Declarations}

\section{Ethical Approval and Consent to participate}

Not applicable.

\section{Consent for publication}

Not applicable.

\section{Availability of supporting data}

Not applicable.

\section{Competing interests}

The authors declare no conflict of interest.

\section{Funding}

Not applicable. 


\section{Authors' contributions}

Liangku Huang, Peng Li conducted the design, study planning, data analysis and data interpretation. Liangku Huang, Peng Li, Haizhen Zhou and Zandong

Zhao wrote and revised the article. All authors read and approved the final manuscript.

\section{Acknowledgements}

None.

\section{Declaration of conflict of interest}

None

\section{References}

1. J. Cabaton, L. Nové-Josserand, L. Mercadal, T. Vaudelin, Analgesic efficacy of ultrasound-guided interscalene block vs. supraclavicular block for ambulatory arthroscopic rotator cuff repair: A randomised noninferiority study, European journal of anaesthesiology 36(10) (2019) 778-786.

2. S.S. Burkhart, Shoulder arthroscopy: a bridge from the past to the future, Journal of shoulder and elbow surgery 29(8) (2020) e287-e296.

3. W.J. Warrender, U.A.M. Syed, S. Hammoud, W. Emper, M.G. Ciccotti, J.A. Abboud, K.B. Freedman, Pain Management After Outpatient Shoulder Arthroscopy: A Systematic Review of Randomized Controlled Trials, The American journal of sports medicine 45(7) (2017) $1676-1686$.

4. C.A. Uquillas, B.M. Capogna, W.H. Rossy, S.A. Mahure, A.S. Rokito, Postoperative pain control after arthroscopic rotator cuff repair, Journal of shoulder and elbow surgery 25(7) (2016) 1204-13.

5. M.J. Fredrickson, S. Krishnan, C.Y. Chen, Postoperative analgesia for shoulder surgery: a critical appraisal and review of current techniques, Anaesthesia 65(6) (2010) 608-24.

6. J.H. Lee, S.H. Cho, S.H. Kim, W.S. Chae, H.C. Jin, J.S. Lee, Y.I. Kim, Ropivacaine for ultrasound-guided interscalene block: 5 mL provides similar analgesia but less phrenic nerve paralysis than $10 \mathrm{~mL}$, Canadian journal of anaesthesia = Journal canadien d'anesthesie 58(11) (2011) 1001-6.

7. W. Zhai, X. Wang, Y. Rong, M. Li, H. Wang, Effects of a fixed low-dose ropivacaine with different volume and concentrations on interscalene brachial plexus block: a randomized controlled trial, BMC anesthesiology 16(1) (2016) 80.

8. S.K. Sinha, J.H. Abrams, J.T. Barnett, J.G. Muller, B. Lahiri, B.A. Bernstein, R.S. Weller, Decreasing the local anesthetic volume from 20 to $10 \mathrm{~mL}$ for ultrasound-guided interscalene block at the cricoid level does not reduce the incidence of hemidiaphragmatic paresis, Regional anesthesia and pain medicine 36(1) (2011) 17-20.

9. F.W. Abdallah, S.H. Halpern, K. Aoyama, R. Brull, Will the Real Benefits of Single-Shot Interscalene Block Please Stand Up? A Systematic Review and MetaAnalysis, Anesthesia and analgesia 120(5) (2015) 1114-29.

10. P.G. McHardy, O. Singer, I.T. Awad, B. Safa, P.D.G. Henry, A. Kiss, S.K. Au, L. Kaustov, S. Choi, Comparison of the effects of perineural or intravenous dexamethasone on low volume interscalene brachial plexus block: a randomised equivalence trial, British journal of anaesthesia 124(1) (2020) 84-91.

11. E. Albrecht, C. Kern, K.R. Kirkham, A systematic review and meta-analysis of perineural dexamethasone for peripheral nerve blocks, Anaesthesia 70(1) (2015) 71-83.

12. R.L. Kahn, J. Cheng, Y. Gadulov, K.G. Fields, J.T. YaDeau, L.V. Gulotta, Perineural Low-Dose Dexamethasone Prolongs Interscalene Block Analgesia With Bupivacaine Compared With Systemic Dexamethasone: A Randomized Trial, Regional anesthesia and pain medicine 43(6) (2018) 572-579.

13. D. Holland, R.J.J. Amadeo, S. Wolfe, L. Girling, F. Funk, M. Collister, E. Czaplinski, C. Ferguson, J. Leiter, J. Old, P. MacDonald, B. Dufault, T.C. Mutter, Effect of dexamethasone dose and route on the duration of interscalene brachial plexus block for outpatient arthroscopic shoulder surgery: a randomized controlled trial, Canadian journal of anaesthesia = Journal canadien d'anesthesie 65(1) (2018) 34-45.

14. D. Moher, A. Liberati, J. Tetzlaff, D.G. Altman, P. Group, Preferred reporting items for systematic reviews and meta-analyses: the PRISMA statement, Journal of clinical epidemiology 62(10) (2009) 1006-12.

15. J. Zhao, W. Huang, S. Zhang, J. Xu, W. Xue, B. He, Y. Zhang, Efficacy of Glutathione for Patients With Cystic Fibrosis: A Meta-analysis of RandomizedControlled Studies, American Journal of Rhinology \& Allergy (2019) 1945892419878315.

16. A.R. Jadad, R.A. Moore, D. Carroll, C. Jenkinson, D.J.M. Reynolds, D.J. Gavaghan, H.J. McQuay, Assessing the quality of reports of randomized clinical trials: Is blinding necessary?, Controlled Clinical Trials 17(1) (1996) 1-12.

17. L.L. Kjaergard, J. Villumsen, C. Gluud, Reported Methodologic Quality and Discrepancies between Large and Small Randomized Trials in Meta-Analyses, Annals of Internal Medicine 135(11) (2001) 982-989.

18. J.P. Higgins, S.G. Thompson, Quantifying heterogeneity in a meta-analysis, Statistics in medicine 21(11) (2002) 1539-58

19. T.M. Sakae, P. Marchioro, F. Schuelter-Trevisol, D.J. Trevisol, Dexamethasone as a ropivacaine adjuvant for ultrasound-guided interscalene brachial plexus block: A randomized, double-blinded clinical trial, Journal of clinical anesthesia 38 (2017) 133-136.

20. E.H. Chun, Y.J. Kim, J.H. Woo, Which is your choice for prolonging the analgesic duration of single-shot interscalene brachial blocks for arthroscopic shoulder surgery? intravenous dexamethasone $5 \mathrm{mg}$ vs. perineural dexamethasone $5 \mathrm{mg}$ randomized, controlled, clinical trial, Medicine 95(23) (2016) e3828.

21. I.B. Botser, T.W. Smith, Jr., R. Nasser, B.G. Domb, Open surgical dislocation versus arthroscopy for femoroacetabular impingement: a comparison of clinical outcomes, Arthroscopy : the journal of arthroscopic \& related surgery : official publication of the Arthroscopy Association of North America and the International Arthroscopy Association 27(2) (2011) 270-8. 
22. C. $29162135 \mathrm{Li}, \mathrm{J} . \mathrm{Qu}$, Efficacy of dexmedetomidine for pain management in knee arthroscopy: A systematic review and meta-analysis, Medicine $96(43)$ (2017) e7938.

23. F.A. Tepolt, J. Bido, S. Burgess, L.J. Micheli, M.S. Kocher, Opioid Overprescription After Knee Arthroscopy and Related Surgery in Adolescents and Young Adults, Arthroscopy : the journal of arthroscopic \& related surgery : official publication of the Arthroscopy Association of North America and the International Arthroscopy Association (2018).

24. D. Tong, F. Chung, Postoperative pain control in ambulatory surgery, The Surgical clinics of North America 79(2) (1999) 401-30.

25. X. Chen, X. Mou, Z. He, Y. Zhu, The effect of midazolam on pain control after knee arthroscopy: a systematic review and meta-analysis, Journal of orthopaedic surgery and research 12(1) (2017) 179.

26. T. Nicholson, M. Maltenfort, C. Getz, M. Lazarus, G. Williams, S. Namdari, Multimodal pain management protocol versus patient controlled narcotic analgesia for postoperative pain control after shoulder arthroplasty, Archives of Bone and Joint Surgery 6(3) (2018) 196.

27. H.S. Jung, K.H. Seo, J.H. Kang, J.-Y. Jeong, Y.-S. Kim, N.-R. Han, Optimal dose of perineural dexmedetomidine for interscalene brachial plexus block to control postoperative pain in patients undergoing arthroscopic shoulder surgery: a prospective, double-blind, randomized controlled study, Medicine 97(16) (2018).

28. E. Calvo, M.D. Torres, D. Morcillo, V. Leal, Rotator cuff repair is more painful than other arthroscopic shoulder procedures, Archives of orthopaedic and trauma surgery 139(5) (2019) 669-674.

29. H. Ullah, K. Samad, F.A. Khan, Continuous interscalene brachial plexus block versus parenteral analgesia for postoperative pain relief after major shoulder surgery, The Cochrane database of systematic reviews 2014(2) (2014) Cd007080.

30. A. Hortense, M.V. Perez, J.L. Amaral, A.C. Oshiro, H.B. Rossetti, Interscalene brachial plexus block. Effects on pulmonary function, Revista brasileira de anestesiologia 60(2) (2010) 130-7, 74-8.

31. O. Stundner, M. Meissnitzer, C.M. Brummett, S. Moser, R. Forstner, A. Koköfer, T. Danninger, P. Gerner, L. Kirchmair, G. Fritsch, Comparison of tissue distribution, phrenic nerve involvement, and epidural spread in standard- vs low-volume ultrasound-guided interscalene plexus block using contrast magnetic resonance imaging: a randomized, controlled trial, British journal of anaesthesia 116(3) (2016) 405-12.

32. B. Attardi, K. Takimoto, R. Gealy, C. Severns, E.S. Levitan, Glucocorticoid induced up-regulation of a pituitary K+ channel mRNA in vitro and in vivo, Receptors \& channels 1(4) (1993) 287-93.

33. M. Desmet, H. Braems, M. Reynvoet, S. Plasschaert, J. Van Cauwelaert, H. Pottel, S. Carlier, C. Missant, M. Van de Velde, I.V. and perineural dexamethasone are equivalent in increasing the analgesic duration of a single-shot interscalene block with ropivacaine for shoulder surgery: a prospective, randomized, placebo-controlled study, British journal of anaesthesia 111(3) (2013) 445-52.

34. F.W. Abdallah, J. Johnson, V. Chan, H. Murgatroyd, M. Ghafari, N. Ami, R. Jin, R. Brull, Intravenous dexamethasone and perineural dexamethasone similarly prolong the duration of analgesia after supraclavicular brachial plexus block: a randomized, triple-arm, double-blind, placebo-controlled trial, Regional anesthesia and pain medicine 40(2) (2015) 125-32.

35. D.M. Rosenfeld, M.G. Ivancic, S.J. Hattrup, K.J. Renfree, A.R. Watkins, J.G. Hentz, A.W. Gorlin, J.A. Spiro, T.L. Trentman, Perineural versus intravenous dexamethasone as adjuncts to local anaesthetic brachial plexus block for shoulder surgery, Anaesthesia 71(4) (2016) 380-8.

\section{Figures}




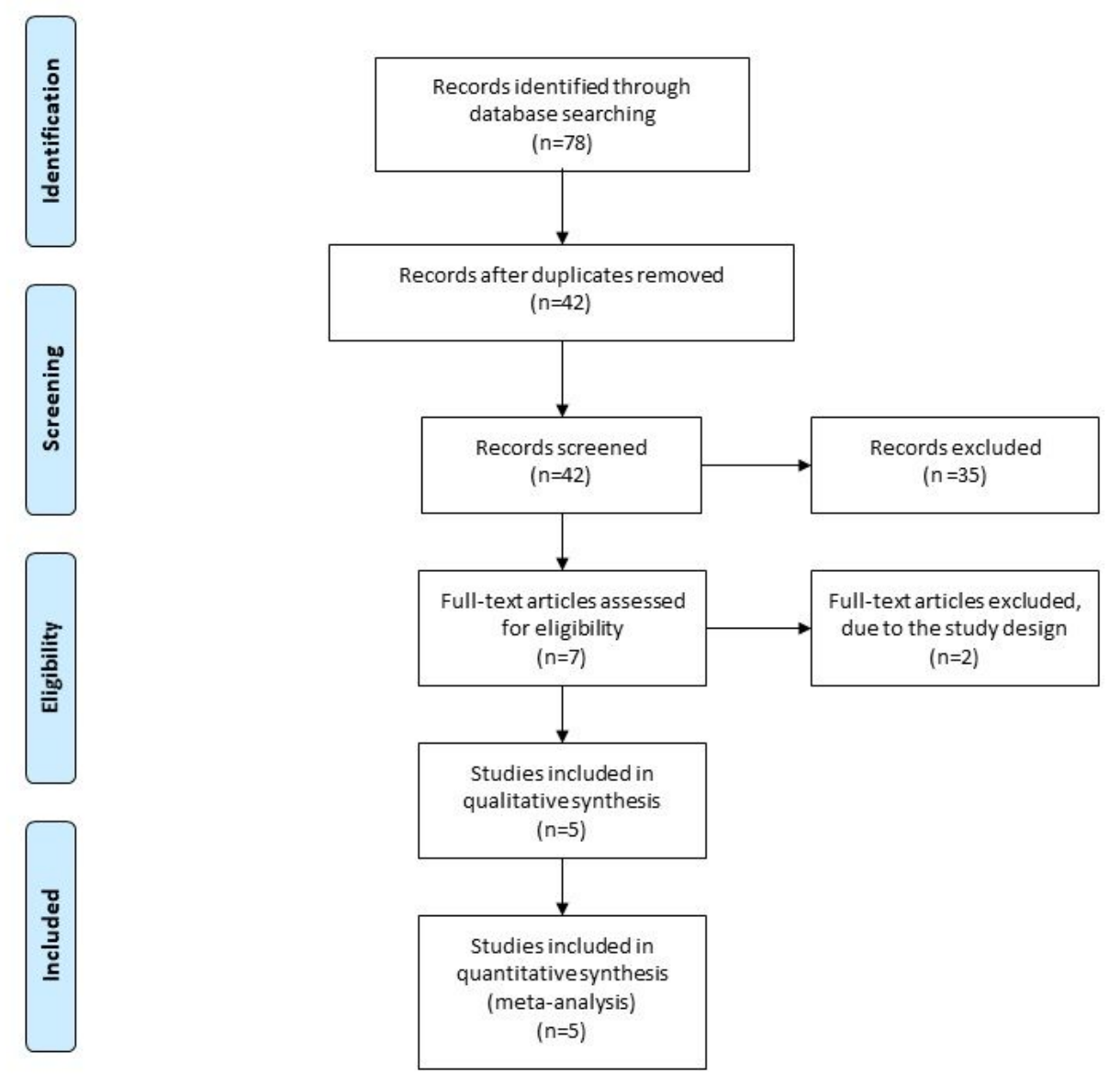

Figure 1

Flow diagram of study searching and selection process.

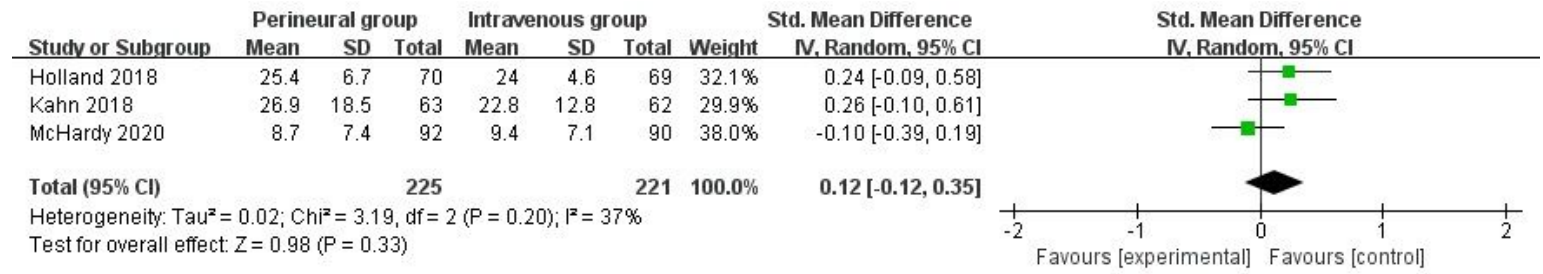

Figure 2

Forest plot for the meta-analysis of block duration.

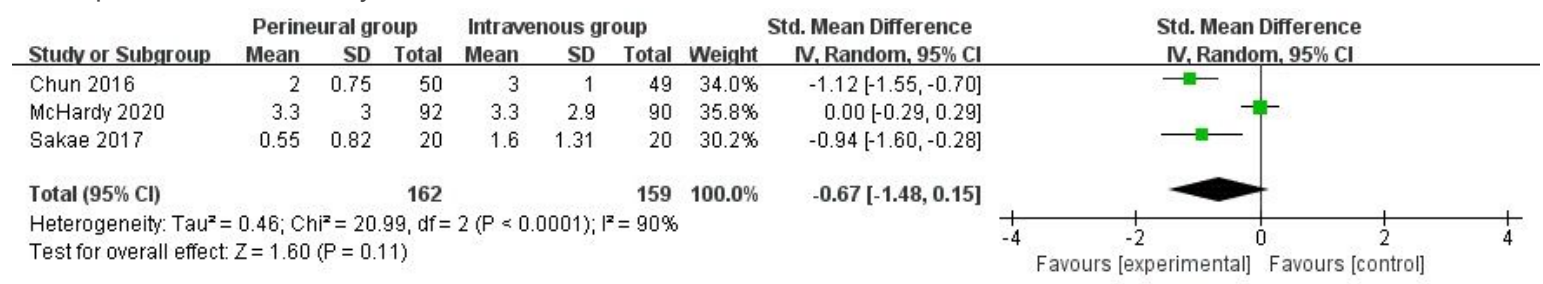

\section{Figure 3}

Forest plot for the meta-analysis of pain scores at $12 \mathrm{~h}$. 


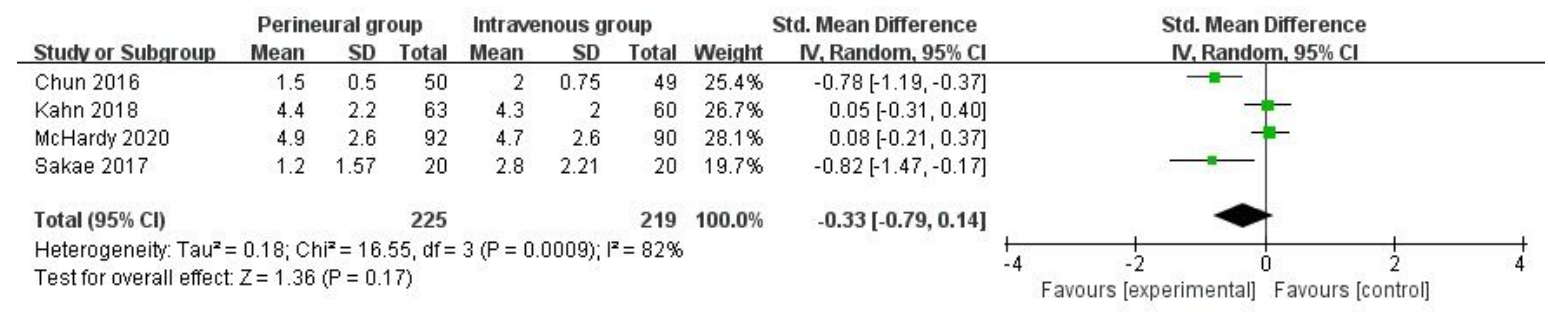

\section{Figure 4}

Forest plot for the meta-analysis of pain scores at $24 \mathrm{~h}$.

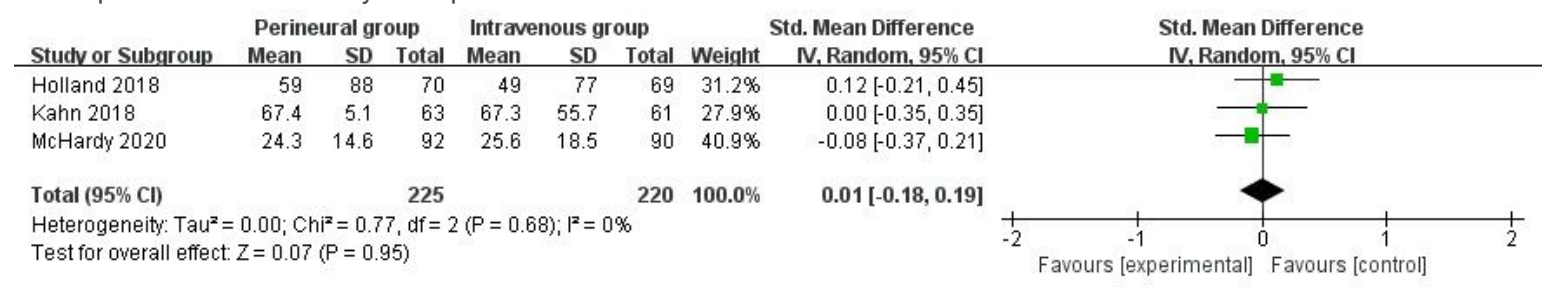

\section{Figure 5}

Forest plot for the meta-analysis of opioid consumption.

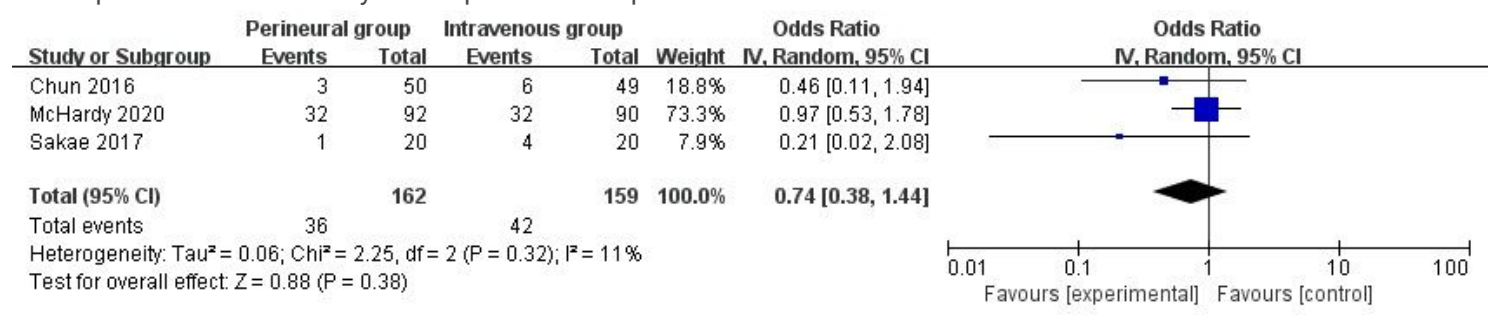

\section{Figure 6}

Forest plot for the meta-analysis of nausea/vomiting. 